\title{
Bilingual Dictionaries and Communicative Equivalence for a Multilingual Society
}

\author{
Rufus H. Gouws, Department of Afrikaans and Dutch, \\ University of Stellenbosch, South Africa
}

\begin{abstract}
In a multilingual society dictionaries play an important role in assisting to achieve communicative success between the speakers of the different languages. Speakers in a multilingual society often employ a bilingual dictionary as the only instrument to meet their lexicographic needs. This implies that a bilingual dictionary becomes a polyfunctional instrument, presenting more information than just translation equivalents. This article focuses on the contents and the presentation of bilingual dictionaries. To achieve the optimal transfer of information for South African bilingual dictionaries, some general problems are identified and discussed. With the emphasis on the user perspective, metalexicographical criteria are used to investigate problems regarding the access structure and the addressing procedures in Afrikaans dictionaries. Suggestions are made to expand the outer access structure and to employ innovative methods, including the use of inserted inner texts, to improve the inner access structure. Changes in the addressing procedures to make provision for the more frequent use of nonlemmatic addressing procedures are also suggested.
\end{abstract}

Keywords: ACCESS STRUCTURE, ADDRESSING PROCEDURES, BILINGUAL DICTIONARY, COMMUNICATTVE EQUIVALENCE, DICTTONARY, INNER ACCESS STRUCTURE, INSERTED TEXT, LEMMATIC ADDRESSING, LEXICOGRAPHY, NON-LEMMATIC ADDRESSING, SEARCH PATH, OUTER ACCESS STRUCTURE, USER PERSPECTTVE

\section{Opsomming: Vertalende woordeboeke en kommunikatiewe ekwivalensie} vir 'n meertalige gemeenskap. In 'n meertalige gemeenskap speel vertalende woordeboeke ' $n$ belangrike rol om kommunikatiewe sukses tussen die sprekers van die verskillende tale te help bewerk. Vir taalgebruikers wat in 'n meertalige gemeenskap woon, is 'n vertalende woordeboek dikwels die enigste woordeboek waaroor hulle beskik. So 'n woordeboek moet gevolglik 'n meerdoelige gebruiksinstrument wees met ' $n$ hoër inligtingslading as net die aanbieding van vertaalekwivalente. In hierdie artikel word die inhoud sowel as die aanbieding van vertalende woordeboeke aan die orde gestel. Om 'n optimale inligtingsoordrag vir Suid-Afrikaanse vertalende woordeboeke te probeer bereik, word sekere tekortkominge aangedui en bespreek. Met die klem op die gebruikersperspektief, word daar aan die hand van metaleksikografiese bevindinge gekyk na probleme met die toegangstruktuur asook die adresseringsprosedures in Afrikaanse vertalende woordeboeke. Die uitbreiding van die eksterne toegangstruktuur en innoverende aanpassings in die interne toegangstruktuur, onder meer die benutting van toegevoegde tekste, word voorgestel. 'n Verskuiwing in die adresseringsprosedures om vir meer gevalle van nielemmatiese adressering voorsiening te maak, word ook voorgestel. 
Sleutelwoorde: ADRESSERINGSPROSEDURES, EKSTERNE TOEGANGSTRUKTUUR, GEBRUIKERSPERSPEKTIEF, INTERNE TOEGANGSTRUKTUUR, KOMMUNIKATIEWE EKWIVALENSIE, LEKSIKOGRAFIE, LEMMATIESE ADRESSERING, NIELEMMATIESE ADRESSERING, SOEKROETE, TOEGANGSTRUKTUUR, TOEGEVOEGDE TEKS, VERTALENDE WOORDEBOEK, WOORDEBOEK

\section{Introduction}

Dictionaries are regarded as containers of knowledge and more specifically as comprehensive sources of linguistic information. This has definite consequences for the article structure of general monolingual and bilingual dictionaries, and implies and necessitates the inclusion of a representative variety of information types as microstructural entries in the treatment of each lemma. In spite of all the different linguistic categories accommodated in each dictionary article, the average user still perceives dictionaries primarily as reference works aimed at the transfer of information on the meaning of words. This attitude of the user often influences the lexicographer when making decisions on the inclusion and presentation of information.

The comprehensive transfer of linguistic information in general monolingual and bilingual dictionaries is often impeded by the presence of a semantic bias that dominates the microstructural presentation. In monolingual dictionaries the focus on the definition and the lack of an extensive treatment of other categories such as grammatical information often illustrates this bias. $\mathbf{A}$ less explicit but often more aggressive application of the semantic bias can be identified in bilingual dictionaries. This procedure is most probably motivated by the typical usage patterns identified in the average dictionary user's utilisation of a bilingual dictionary. Users focus their lexicographical inquiries on semantic aspects in their search for "the target language meaning of a source language item". Having found a target language item, no further attention is paid to additional information which might be of paramount importance for the correct comprehension or use of the specific item. Users too often eschew the other entries which form an integral part of the overall linguistic treatment of a lemma.

The status of a bilingual dictionary as a source of semantic information is especially evident in a multilingual society. In a monolingual society, bilingual dictionaries are not used as reference works in the day to day linguistic needs of the average member of a speech community. Monolingual descriptive dictionaries are employed for this function. In a multilingual society the use of bilingual dictionaries forms an integral part of the daily communication process. Where the majority of dictionary owners in a monolingual society will possess a monolingual dictionary, a multilingual society gives evidence of the flip side of the coin with bilingual dictionaries being possessed by the majority of one-dictionary owners. They employ their bilingual dictionaries not only as 
encoding or decoding aids during translation, but the dictionary functions as the only source of semantic information for both the native and the foreign language treated in the dictionary. If you need to know the meaning of a word from the lexicon of your native language you consult a bilingual dictionary and interpret the meaning from the given translation equivalents. A bilingual speaker can often use a bilingual dictionary with success to obtain semantic information regarding his native language. For the skilful dictionary user who is competent in both languages the listing of translation equivalents without the interference of other microstructural entries can be used for instant semanticising. However, this is only possible where the dictionary user is very skilful. Lexicographers may not rely on the presumed intuition of their users but have to be as explicit as possible to ensure an optimal transfer of information. This implies the inclusion of additional entries not aimed directly at transferring the meaning of the lemma but rather at supporting and supplementing the given translation equivalents.

Although bilingual dictionaries are employed as polyfunctional sources of semantic information, their main function is not a transfer of meaning. Bilingual dictionaries are aids in interlingual translations and have to focus on a treatment that enables the user to render a good and sound translation. The main aim of the dictionary should not only be the establishment of a relation of semantic equivalence between source and target language. Instead, a lexicographer has to endeavour to reach communicative equivalence.

\section{Translation equivalents and translation equivalence}

When people consult a bilingual dictionary they seldom realise that the information given is not essentially a statement about meaning but a list of translation equivalents, cf. Louw $(1985: 53,54)$. The functional status of these translation equivalents is that they may be used in certain contexts to substitute the source language item. Where the specific contexts in which translation equivalents can be used to substitute the lemma are not given as part of the lexicographical treatment, it is hardly possible that the creation of semantic equivalence can lead to the establishment of communicative equivalence.

A relation of equivalence exists between a lemma and the translation equivalent paradigm, that is the selection of translation equivalents presented in the article of any one lemma. Translation equivalence, the first aim of the lexicographer of a bilingual dictionary, implies a semantic co-ordination between a lemma and its translation equivalent paradigm. Unfortunately, lexicographers often restrict their attempts to ensure translation equivalence to the mere listing of a number of target language items. Although these items represent the semantic value of the lemma and create a relation of semantic equivalence, the dictionary user receives no assistance in choosing the correct equivalent for a specific context. This lack of additional information impedes the 
possibility to reach communicative equivalence; the form of equivalence that should be the lexicographer's first priority.

The existence of different types of equivalent relations adds to the problems of the dictionary user in his attempts to utilise a bilingual dictionary as a functional linguistic instrument. Where congruence holds as equivalent relation, there is a one-to-one relation between source and target language. In such an article semantic equivalence generally implies communicative equivalence. In the case of a relation of divergence there is a one to more than one relation between source and target language. In these articles the lexicographer has to distinguish between lexical and semantic divergence, and this distinction must have an influence on the microstructural representation, cf. Gouws (1989: 167). Lexical divergence is the equivalent relation between a lemma and a translation equivalent paradigm or a subsection of such a paradigm, where all the members of the paradigm are synonyms. Semantic divergence comes into play when the members of the paradigm are not synonyms because the lemma is a polysemous lexical item and different translation equivalents are needed to represent the different polysemous senses of the lemma. Both types of divergence often occur in one article. In the Afrikaans-English / English-Afrikaans dictionary Tweetalige woordeboek / Bilingual Dictionary, the following translation equivalent paradigm is given in the article of the polysemous lexical item betrokke:

betrokke "overcast, cloudy, dull (sky); clouded (face); concerned; relevant; committed, involved ..."

Although the first three translation equivalents are only partial synonyms they can be used to substitute the lexical item betrokke in the same context because they represent one polysemous sense of this lexical item. Between the lemma and these target language forms exists a relation of lexical divergence. The other target language items, e.g. concerned, relevant and committed, represent other polysemous senses of the word betrokke. This illustrates a relation of semantic divergence.

According to Zöfgen (1991: 2889) the use of an alphabetically arranged dictionary presupposes a specific communication situation, and requires skill in acknowledging lexical shortcomings as well as the ability to find a reference form for them. One of the major problems of the user of a bilingual dictionary arises in articles with divergence as equivalent relation. To ensure communicative equivalence the dictionary article has to accommodate additional entries to support the given semantic information. This will be the focus of the rest of this paper.

\section{Criteria for modern bilingual dictionaries}

In utilising the results of the metalexicographical research done in the past two 
decades, lexicographers can apply a number of well-formulated criteria to improve the quality of their dictionaries. Kromann et al. (1991: 2713) argue convincingly in favour of three criteria applicable in the evaluation and compilation of bilingual dictionaries. They are the user aspect, the linguistic aspect and the empirical aspect. The user aspect focuses on ascertaining a specific target user group and on the distinctive lexicographical needs of this target group. The empirical aspect includes the establishment of relevant databases and the collection of material, whereas the linguistic aspect demands a systematic approach from the lexicographer in the treatment of equivalent relations between lexical fields of the source and the target language but also in the treatment of other syntagmatic and paradigmatic relations that exist between these fields. Both the empirical and the linguistic aspects may not be isolated from the framework set by the user aspect.

The importance that Kromann et al. (1991) attach to the user aspect is in line with one of the mainstream research areas in present-day metalexicography, i.e. dictionary use and the focus on the dictionary user, his needs and reference skills, cf. Hartmann (1989; 1989a), Kühn (1989) and Zöfgen (1994). The position of the user is so important that Hartmann (1989: 103) hypothesises that an analysis of users' needs should precede dictionary design. This implies that the design of a dictionary in terms of both its macro- and its microstructure has to be co-determined by the needs and reference skills of the intended target user. The user perspective can have such a comprehensive influence on the design of a dictionary that it could alter its proposed typological status. In meeting the needs of a well-defined target user, the lexicographer might find it necessary to deviate from the traditional criteria for certain dictionary types. Adhering to the demands of the user perspective may lead to a reassessment of existing typological classifications and to a more precise functional differentiation within these categories. The use of bilingual dictionaries in a multilingual society necessitates a comprehensive profile of the target user, his needs and reference skills. Divergence compels the lexicographer to present the target language information in such a way that the intended user will be able to make an unambiguous choice of the correct equivalent for any specific context.

A reassessment of the category of bilingual dictionaries gives evidence of the need for a detailed subtypological categorisation. This topic will not be discussed in this paper, although certain remarks, suggestions and proposals will underline the need for such a refined typological classification.

\section{Bilingual dictionaries: a typological perspective}

Considering the different needs and reference skills of users when consulting a bilingual dictionary, one has to argue in favour of a differentiation within this typological category. One bilingual dictionary cannot be everything to everyone. The collection of Afrikaans bilingual dictionaries, that is bilingual dictionaries with Afrikaans as one of the members of the language pair to be treated 
in the dictionary, displays a lack of subtypological differentiation. This is a symptom of a more general problem, which influences many dictionaries in many ways, caused by an insufficient linguistic and metalexicographical basis.

Although a distinction is made between different types of Afrikaans bilingual dictionaries, the metalexicographical motivation for this distinction is insignificant. Too often an Afrikaans bilingual dictionary professes to be compiled for use at school level. However, an evaluation of the dictionary gives evidence that the microstructural treatment is not directed at the needs of the target user. School dictionaries are often produced as spin-offs from general dictionaries. In many of these cases, cf. Gouws (1995: 19; 23), the lexicographer diminishes the macrostructure of the existing general dictionary and omits some of the microstructural entries to produce a new dictionary without any real attention to the needs of the new target user. Each typological category has to be compiled with the specific target user in mind, adhering to specific macro- and microstructural demands and criteria.

According to Zöfgen (1994: 16) the conception of future dictionaries will have to follow a lexicographical-pragmatic approach orientated at at least three parameters, i.e. the user, the situation in which the dictionary will be used and the nature and extent of the information to be treated in the dictionary. This approach deviates from a lexicographical tradition which only focuses on the transfer of information, and it emphasises the importance of the user in modern-day lexicography. There often exists a gap between the claims of publishers and lexicographers and the real efficiency of a dictionary for its specific target user. Zöfgen (1994: 245) argues that the usage value of a dictionary is often inversely proportional to the promises of the publisher. Within a multilingual society, the optimalization of the added value which a bilingual dictionary can have for its target user depends on the lexicographer's knowledge of the real needs of that user.

\section{The access structure of bilingual dictionaries}

Dictionaries display three major structural components, i.e. the macrostructure, microstructure and access structure, cf. Hausmann and Wiegand (1989). The macrostructure can be regarded as the collection of lemma signs being the basic treatment units of the dictionary, whereas the microstructure is the total set of data categories following the lemma sign. The dictionary user has to get to the information he needs, and the structure of the dictionary should help him to reach that information. This component of the dictionary is known as the access structure. A distinction is made between the outer access structure and the inner access structure. The outer access structure guides the user up to the lemma, whereas the inner access structure helps the user to reach the specific information category within the article. The access structure can also be described as the search path for the dictionary user. 
One of the possibilities a lexicographer should consider to enhance the user-friendliness of his dictionary, is to improve the quality of the access structure in such a way that the search path can lead to an instant retrieval of information. Besides the distinction between the outer and the inner access structure, a lexicographer should pay attention to a third possible component in the access structure, i.e. a component providing a search path from the inner access structure to the communicative context in which the specific lexical item is to be employed. This component can be called the communicative access structure or the exit structure.

Where a bilingual dictionary is compiled for users who are L1 speakers of one of the languages of the dictionary, with a certain level of efficiency in the second language and who share the same cultural background, the traditional outer access structure of a monoaccessible bilingual dictionary would be quite sufficient. This would apply in a bilingual country where both languages are compulsory school subjects and where every speaker has a relative good command of the second language. This situation motivated the present state of bilingual Afrikaans-English / English-Afrikaans dictionaries. In the previous political dispensation Afrikaans and English were the only two official languages of South Africa. Afrikaans- and English-speaking South Africans had a fairly good command of both languages and the Afrikaans-English / EnglishAfrikaans bilingual dictionaries relied, admittedly often too much, on the knowledge of the intended target user. This approach to bilingual dictionaries has not only had a detrimental influence on Afrikaans-English / EnglishAfrikaans dictionaries, but it impeded the development of other South African bilingual dictionaries due to the role-model influence of the leading AfrikaansEnglish dictionaries, cf. Gouws and Ponelis (1992) and Gouws (1993). A lexicographical result of this situation is that a single search path in both the outer and inner access structure was a typical characteristic of Afrikaans-English / English-Afrikaans as well as other bilingual South African dictionaries.

In the new political dispensation South Africa has eleven official languages, i.e. Afrikaans and English; the Nguni languages isiXhosa, isiZulu, siSwati and isiNdebele; the Sotho languages Sesotho sa Leboa and Sesotho, and Setswana as well as Tshivenda and Xitsonga. This has definite implications for the nature and extent of bilingual dictionaries. One of these implications is the fact that lexicographers compiling bilingual dictionaries may no longer assume their target users to be familiar with both the languages treated in the dictionary. This leads to a situation where dictionary users need more guidance to ensure a successful retrieval of information. One way of achieving this is to enhance the accessibility of the dictionary by improving the quality of the access structure.

\section{Improving the outer access structure}

Changes to the outer access structure could be done in various ways. On the 
one hand the lexicographer could add special entries or alter the presentation of macrostructural elements and, on the other hand, the lexicographer could include additional access structures to create a poly-accessible dictionary. Existing dictionaries can be used to illustrate both these options.

Special entries in the form of structural markers as well as a typographical innovation to change the face of certain lemma signs have been employed by the bilingual learner's dictionary Kenkyusha's Lighthouse English-Japanese Dictionary. This dictionary employs asterisks on a systematic basis as structural markers to indicate lemmas with a high usage frequency and to give the user access to the core vocabulary. This system grades certain lemma signs with between one and four asterisks. One asterisk indicates that the lemma belongs to the 3000 basic words of general usage; two asterisks indicate membership of the first 2000 basic words of general usage; three asterisks mark a lemma as part of the first 1000 basic words for high school usage whereas four asterisks signal a word as belonging to the first 1000 basic words for junior high school. In addition to this system the Lighthouse Dictionary gives rapid access to the last two categories of words by presenting the lemma signs in a larger letter type and coloured red. By merely following the outer search path a user looking for this type of information can easily distinguish these lemmas from the rest of the macrostructure without having to resort to an article internal search.

The Reader's Digest Afrikaans-Engelse Woordeboek / English-Afrikaans Dictionary (hereafter abbreviated as $\mathrm{RD}$ ) owes its poly-accessible character to the inclusion of additional outer access structures. The central word list is the same text used in another bilingual Afrikaans-English / English-Afrikaans dictionary, i.e. Tweetalige woordeboek / Bilingual Dictionary (hereafter abbreviated as TW). One of the major problems of TW is that it has traditionally been directed at a bilingual target user. This dictionary, albeit one of the best members of its typological category, demands too much linguistic and pragmatic insight from a user who is unfamiliar with one of the treated languages. The editor of RD has detected this problem, but a contractual stipulation forbids changes to the central word list. This restriction has proved to be a lexicographical bonus because it has led to the introduction of an innovative alternative to enhance the attempt at communicative equivalence.

The original macrostructure of $\mathrm{RD}$ is presented in two columns occupying the centre of each page. An additional column is included on either side of the central word list. These columns contain two kinds of entries - clearly distinguished from each other. On the one hand, and of less importance for the present discussion, there are boxes called "Words in action" in which a word, taken from the macrostructure, is repeated and supplied with additional information on pragmatics, semantics, grammar, etc. The information in these boxes is given against either a blue background ("Words in action", in the AfrikaansEnglish component where the information, given in English, refers to Afrikaans words) or against a pink background ("Woorde in aksie", in the EnglishAfrikaans component where the information, given in Afrikaans, refers to 
English words). On the other hand these columns contain an additional access structure which is a second, much reduced macrostructure. This supplementary text contains lemmas also treated on the same page in the main text of the central word list.

The treatment in the articles of this supplementary text is directed at the user who cannot choose the correct translation equivalent from the presentation in the article of the main text. One of the problems of the translation equivalent paradigm in the main text, which is actually a problem of TW, is a lack of contextual information to support the translation equivalents. Ever so often an uncommented list of translation equivalents gives no assistance to the user who does not know which equivalent will be the correct choice for the specific context in which he needs to use the word. The specific contents of these supplementary text articles will be commented on in another section of this paper. Here it will suffice to mention that the focus in these articles is on a retranslation of the translation equivalents.

Although the front matter of RD does not give criteria for the selection of lemmas to be included in this secondary macrostructure, it can be argued that semantic divergence is one of the dominating reasons for the selection. What is important here is the information conveyed to the user on the search path of the outer access structure. RD allows access to the main text as well as to the supplementary text. Being familiar with the system employed in this dictionary, the user who consults the dictionary for a translation equivalent of a specific word, will follow the primary search path to the main text lemma he is looking for. Knowing that $\mathrm{RD}$ offers a retranslation of certain lemmas where an insufficient treatment of semantic divergence as equivalent relation impedes the retrieval of a communicative equivalent, the user should turn to the supplementary text to see if the lemma of the main text is also presented in the supplementary text. If there is no such lemma the user can proceed to the inner access structure of the main text article. The occurrence of the wanted lemma as part of the supplementary macrostructure will lead the user to the inner search path of that article where a more comprehensive treatment is given. The inclusion of this additional access structure increases the functionality of the dictionary because it helps the user to a quicker and unambiguous retrieval of the desired information.

\section{Improving the inner access structure}

A variety of information categories have to be provided for by the microstructure of both bilingual and monolingual dictionaries. A microstructure typically displays a linearly ordered set of information categories and the search path of the inner access structure leads a dictionary user from the top of this ordering down to the bottom. One of the many problems experienced by dictionary users is the unclear division between information categories. Especially in a 
dictionary with a high density of information it takes time to identify a specific microstructural category before being in the position to retrieve the necessary information.

A user-orientated dictionary should try to empower its users by constructing the article in such a way that a quick and unambiguous retrieval of information, preceded by a successful identification of the wanted microstructural category, is always possible. This means that the user has to be familiar with the inner structure of the articles in the dictionary and with the order of the different article positions. The inner access structure can be improved by providing structural markers to indicate the borders between information categories as well as the position and scope of different search areas.

In the Afrikaans-English / English-Afrikaans Tweetalige Aanleerderswoordeboek / Bilingual Learner's Dictionary (hereafter abbreviated as TAW), the inner access structure contains structural markers to indicate different types of microstructural categories. Following the system used in monolingual dictionaries to differentiate between polysemous senses, TAW gives a number for each translation equivalent representing a different polysemous sense of the lemma. The occurrence of collocations is always preceded by a diamond, and the search area containing article positions which accommodate the part of speech and information about forming plurals or other derived forms, is marked by a small square. In the descriptive monolingual Afrikaans dictionary Verklarende Handwoordeboek van die Afrikaanse Taal the inclusion of cited examples is marked by an upside down triangle. These structural markers are part of the access structure and their function is to guide the user to a specific information category.

In his analysis of the lexicographical text formation Wiegand (1995) makes provision for the inclusion of inserted inner texts as part of the article, and he regards this type of text as especially appropriate for learner's dictionaries. These inserted inner texts can easily be distinguished from the rest of the article because they are presented in a different manner, e.g. in boxes or tables. If the lexicographer wants to draw the attention of his intended target user to a specific aspect of a lemma, the inclusion of an inserted inner text will be a clear milestone on the search path of the inner access structure. This system is employed in TAW for the presentation of additional information, mostly of a pragmatic nature, not covered by the defined categories in the ordered article positions. The articles of the lemmas meat and scissors contain the following inserted inner texts respectively:

The meat from some animals has a different name from the animal itself: the meat from a cow is called beef and that from a pig pork, but the meat from a lamb is called lamb. For fish and for birds such as chicken or duck the same word is used for both meat and animal. 
scissors take a plural verb, but a pair of scissors is singular. "Where are the scissors?" This pair of scissors is mine.

The inserted texts in TAW are not only characterised by their occurrence on microstructural level, but also by their macrostructural functioning. Inserted texts help to constitute the macrostructure and form part of the outer access structure. The lemma examination in TAW is preceded by an inserted text as an additional article:

exam is an abbreviated, informal word for examination (its plural is exams)

Between the articles of the lemmas hanger and happen the boxed article of the lemma hanky is included as an inserted text:

hanky is an informal word for handkerchief (its plural is hankies)

These inserted texts add some diversity to the macrostructure. Their boxed presentation within the outer access structure enhances the procedure of identifying a certain category of macrostructural elements.

The kind of article formation where inserted texts are used, illustrates an approach that is aimed at a more comprehensive transfer of information with a strong communicative focus. In a multilingual society lexicographers will do well to include inserted inner texts in their attempt to enhance the communication skills of the intended target user of their dictionary. The use of inserted inner texts is not restricted to bilingual dictionaries. In monolingual dictionaries, especially learner's dictionaries, these constituents can be functional text components. In the monolingual Afrikaans learner's dictionary Basiswoordeboek van Afrikaans text boxes add valuable pragmatic information, cf. the use of one of these inserted inner texts in the article of the lemma afbrand:

Afbrand word meestal ten opsigte van geboue gebruik. ' $n$ Motor wat deur vuur vernietig word, sal uitbrand.

(Afbrand (to burn down) is generally used to refer to buildings. If a car is destroyed by fire it will burn out.)

The inner access structure should also contain information to guide the user to related articles or to the practical application of microstructural information in the real language context. To enable users following the search path of the 
inner access structure to achieve rapid access to these microstructural entries, the lexicographer should also employ structural markers to indicate the relevant article positions. TAW uses arrows to refer a user to another lemma. In the article of the lemma cow the user is directed by means of an arrow to the note (the inserted inner text) in the article of the lemma meat, whereas the only article position in the article of the lemma till is the arrowed reference to until. In the Kenkyusha's Lighthouse Dictionary an even more explicit structural marker is used for intra-article reference. A pointed hand precedes the cross-reference and forms a clearly noticeable signpost on the inner search path.

Intra-article structural markers place the lemma and its translation equivalents into communicative contexts while inter-article structural markers help the user to see further than the isolated lemma by displaying the lexicon as a network of semantic relations and the dictionary as a text with a definite cohesion.

\section{The addressing procedure in bilingual dictionaries}

According to Hausmann and Wiegand (1989: 328) the way in which a form and information relating to that form are brought together is the addressing procedure. Each information item is addressed to a form called the address. In a dictionary article the addressing procedure occurs when information is related to the lemma (the form). The lemma is the most typical lexicographical address and is always the target of lemmatic addressing. However, information can also be directed at other components of the article and display a non-lemmatic addressing procedure. In bilingual dictionaries lexicographers should give much more consideration to the use of non-lemmatic addressing procedures. The implementation of these procedures can add to the enhancement of communicative equivalence. This aspect will be discussed in a following section.

\section{Lemmatic addressing}

Linguists working in the field of lexical semantics have drawn attention to the existence of lexical gaps, cf. Lehrer (1974) and Lyons (1977). Lexical gaps are language-specific and this poses problems to the lexicographer compiling a bilingual dictionary. Dagut (1981) identifies different types of semantic gaps in the transfer of a text from one language to another. He distinguishes between gaps due to linguistic factors and gaps due to extra-linguistic factors. These two categories are called linguistic and referential gaps respectively.

A linguistic gap exists where the speakers of both languages are familiar with a certain object but where the one language does not have a word to refer to the object, whereas the other language does have such a word. A referential gap can be postulated where a lexical item from language $A$ has no translation 
equivalent in language $B$ because the speakers of language $B$ do not know the referent of the lexical item from language $A$.

To achieve communicative equivalence a lexicographer has to identify potential lexical gaps and distinguish between linguistic and referential gaps. This distinction determines the extent of the additional information needed for an optimal transfer of semantic and pragmatic information. Lexical gaps in the target language of a bilingual dictionary compel the lexicographer to employ a more detailed lemmatic address. Linguistic gaps offer less serious problems to a lexicographer because the speakers of the language with these gaps are familiar with the object to which the non-existing word would have referred. Quite often a loanword is used as a surrogate equivalent. To ensure a proper transfer of the meaning of the lemma, lexicographers complement the surrogate equivalent by including a brief description.

The game of rugby is known to speakers of all the different South African languages. However, all these languages do not have translation equivalents for this word and the loanword is often used as a surrogate equivalent. The monodirectional Afrikaans-Zulu dictionary Afrikaans / Zoeloe-woordeboek, compiled for the South African market, has the lemma rugby with the surrogate equivalent in Zulu iragbhi. This equivalent is followed by the brief explanation ibhola lombhoxo which literally means "the ball of an oval object." This entry has a lemmatic address because it explains something of the meaning of the lemma. The Nguni languages have a word ubuntu which has no one-to-one translation equivalent in English. The best attempt would be human-heartedness. In the Dictionary of South African English the equivalent human-heartedness is given, but this entry is followed by the brief explanation "quality embodying all the traditional virtues and values of isintu ..." The word isintu refers to African characteristics, style, values and traditions. The inclusion of the explanation enhances the communicative equivalence because the user will know that the translation equivalent human-heartedness is not an exhaustive equivalent of the lemma. Once again an additional lemmatic addressing procedure is employed to ensure a more comprehensive treatment.

Even though the speakers of a certain language may be well familiar with a specific referent where their language has a linguistic gap, the lexicographer should, once again, not rely on the intuition of his users, but by means of additional lemmatic addressing procedures he has to be as explicit as possible in the transfer of information to ensure a sound understanding of the lemma as well as the communicatively correct application of a possible surrogate equivalent. The failure to do so can cause real problems. Afrikaans-speaking South Africans are well familiar with the referential value of the lexical item fat cat. However, Afrikaans has a linguistic gap with no real translation equivalent for this item. Where no satisfactory surrogate equivalent can be found, the lexicographer of a bilingual English-Afrikaans dictionary should restrict the treatment of the lemma fat cat to a brief description addressed at the lemma. TW treats this lemma by giving the surrogate equivalent rykaard (person of wealth). 
Besides the semantic differences between fat cat and rykaard there is also a difference in register. No additional information is given to convey the real meaning and register of the lemma. The lack of either an additional lemmatic addressing procedure or a non-lemmatic addressing procedure to give more information on the surrogate equivalent impedes communicative success.

Because a referential gap implies that the speakers of the language are not familiar with a certain referent, the lexicographer is compelled to treat the lemma in a more comprehensive manner. The multilingual South African society is also a multicultural society. Cultural traditions amongst the speakers of a language group are often unknown to speakers of the other languages. This leads to referential gaps and poses many a problem for the lexicographer. The lexicographer should still endeavour to find a surrogate equivalent but the article has to contain an additional microstructural treatment of the lemma to ensure the retrieval of the correct information.

The Nguni word hlonipa "refers to a system of reverence and taboos observed by the Nguni woman towards her male relatives-in-law, involving a whole substitute vocabulary of (hlonipa) words to avoid speaking the radical syllable of any one of their names ..." (Dictionary of South African English). Hlonipa is used as a loanword in South African English and Afrikaans. Yet the treatment of this lemma in a bilingual Zulu / Xhosa-Afrikaans / English dictionary needs additional lemmatic addressing in the article of this lemma. By merely giving the loanword or an unsatisfactory surrogate equivalent, e.g. taboo, the user is not equipped with sufficient information.

\section{Non-lemmatic addressing}

The addressing procedure in both monolingual and bilingual dictionaries is dominated by lemmatic addressing. Although the lemma remains the main treatment unit of a dictionary with the majority of microstructural entries directed at the lemma, users also need information regarding other microstructural items, e.g. translation equivalents. In a bilingual dictionary lemmatic addressing keeps the lexicographical focus only on the source language item, and ignores one of the most fundamental differences between bilingual and monolingual dictionaries in terms of the treatment of semantic information. Semantic information in a monolingual dictionary focuses necessarily on the lemma. Hansen (1990: 97) argues that the presentation and ordering of translation equivalents should be determined by the equivalence relations between the lemma and the translation equivalents and not by the semantic structure of the lemma, as is the case with the ordering of polysemous senses in a monolingual dictionary. The co-ordination of two languages in one reference work often necessitates the elucidation of some of the target language items. Hansen's formulation already indicates a focus shift in the presentation of semantic information in a bilingual dictionary. This is ascertained by Hausmann and Werner (1991: 2730), according to whom the principle of meaning 
discrimination applied in a monolingual dictionary should be replaced in bilingual dictionaries by a principle of equivalent discrimination. Such an approach does not eschew the importance of the presentation of semantic information in bilingual dictionaries. It rather represents a shift in the semantic focus from the lemma to the equivalent. While the mere listing of translation equivalents without any complementary or supporting entries adheres to a lemmatic addressing procedure, the focus shift towards the translation equivalent paradigm implies an article-internal non-lemmatic addressing procedure. Non-lemmatic addressing procedures in bilingual dictionaries are mostly directed at the translation equivalent. Equivalent discrimination still implies the transfer of semantic information and even the discrimination of meaning. This discrimination is directed at the need of the dictionary user to get familiar with the target language items.

The habit of focusing on the meaning of the lemma has led to the presentation of semantic equivalence as the prime objective of the lexicographical treatment in bilingual dictionaries. This lemmatic addressing eschews the need for sufficient contextual evidence which is a type of information primarily directed at the translation equivalent and therefore constitutes a non-lemmatic addressing procedure.

For a bilingual dictionary to function as a practical linguistic instrument in a multilingual and multicultural society the information transfer has to be focused on pragmatic aspects. There is a fundamental difference between the demands of foreign language users and those of native speakers, and therefore lexicographers have to employ innovative approaches to make the information in their dictionaries accessible to the intended target user. The demands of the users of bilingual dictionaries in a multilingual society must be dealt with from a functional and pragmatic perspective which gives first priority to the usefulness of the treatment to the target user. A reassessment is needed of the traditional treatment of semantic information in bilingual dictionaries. The way in which illustrative examples, with a translation equivalent as address, can equip a user with semantic information, can exceed the transfer of semantic information achieved by traditional methods focusing on the lemma.

In a lemmatic addressing procedure the lemma is the topic and the information related to the address is the comment. Non-lemmatic addresses imply a constant topic switching because every new address is a new topic within the article, cf. Hausmann and Wiegand (1989: 328, 329). Although topic switching increases the density of information, the new comment is directed at a topic with which the user is unfamiliar, being a translation equivalent in the target language. The additional information adds communicative value and empowers the user with better comprehension.

There are various types of non-lemmatic addressing aimed at an enhancement of communicative equivalence in bilingual dictionaries. This includes the use of glosses, collocations, illustrative phrases and sentences, the explanation of meaning as well as ostensive addressing, i.e. the use of pictorial 
illustrations. In equivalent relations of semantic divergence microstructural entries like these form a significant part of the dictionary article.

Hansen (1990: 3) distinguishes between the translation profile and the example profile in a bilingual dictionary. The translation profile contains the translation equivalents and all the information directly relevant to the translation equivalents. The example profile contains the illustrative examples and all the information directly relevant to the examples. According to Hansen the lemma and the translation profile constitute the compulsory components of the article of a bilingual dictionary while the example profile is in principle optional. For a sophisticated dictionary user who is familiar with both the languages treated in a bilingual dictionary, Hansen's argument might hold, because this user does not need the examples to contextualize the translation equivalent. However, in a multilingual society the lexicographer may neither presuppose this kind of expertise from the target user nor may he rely on the intuition of the user to interpret the translation equivalent correctly for a specific context. The use of examples represents a pragmatic non-lemmatic address and offers an interaction of semantics and grammar in order to equip the user with encoding and decoding skills. It can also help to differentiate between a stylistic adequate text presentation and the mere understanding of a foreign text, cf. Kühn (1989: 117, 118).

In $\mathrm{RD}$ the alternative outer access structure leads the user to the supplementary text in which the lexicographer has employed an innovative method of retranslating the equivalents in order to ensure a correct choice and a pragmatic and linguistically sound application. The main text of RD, which is also that of TW, treats semantic divergence unsatisfactorily. For many of these uncommented translation equivalent paradigms, RD has created new articles in which the translation equivalents are the topics of non-lemmatic addressing procedures. In the English-Afrikaans section the lemma pinnacle (noun) gets the following treatment in the translation equivalent paradigm:

torinkie, toringspits; spits torinkie; siertorinkie, pinakel (bouk.); top, spits, piek; hoogste punt, toppunt.

In the supplementary text the lemma pinnacle gets a lemmatic address with the inclusion of all the translation equivalents given in the main text. A nonlemmatic address provides each one of these translation equivalents with information on pronunciation as well as a retranslation:

torinkie turret; toringspits spire, steeple; spits torinkie pointed turret; siertorinkie and pinakel slender turret or spire on a roof; top top, peak, summit; spits peak, summit, spire; piek peak; hoogste punt acme, culmination, peak, zenith, highest point; toppunt top, summit, highest point, acme. 
Semantic divergence implies either a polysemous lemma or the translation equivalent paradigm of a monosemous lemma which includes at least one polysemous translation equivalent. Although RD's retranslation does not provide contextual entries, glosses or explanations, the non-lemmatic addressing gives an indication of the different relations of equivalence between the lemma and the translation equivalents of the main text article. This procedure enhances communicative skills. A different kind of access structure can be identified in these articles. The retranslation gives access from the target language back to the source language. This is an access structure to promote the correct use of the translation equivalent in real communicative situations. It can be regarded as a communicative access structure or an exit structure from the article to the pragmatic functioning of the translation equivalent.

\section{Conclusion}

In a multilingual and multicultural society bilingual dictionaries have to provide translation equivalents. What is, however, of prime importance, is an additional treatment aimed at the differentiation of these equivalents. By skilfully adjusting the access structure and by an innovative application of addressing procedures the dictionary article can offer a presentation of communicative equivalents instead of merely semantic equivalents.

\section{References}

Bosman, D.B. et al. 19848. Tweetalige woordeboek / Bilingual Dictionary. Cape Town: Tafelberg Publishers.

Branford, J. and W. Branford. 19914. Dictionary of South African English. Cape Town: Oxford University Press.

Dagut, M. 1981. Semantic Voids as a Problem in the Translation Process. Poetics Today 2(4): 61-71.

Du Plessis, M. 1993. Tweetalige Aanleerderswoordeboek / Bilingual Learner's Dictionary. Cape Town: Tafelberg Publishers.

Gouws, R.H. 1989. Leksikografie. Cape Town: Academica.

Gouws, R.H. 1993. Afrikaans Learner's Dictionaries for a Multilingual South Africa. Lexikos 3: 29-48

Gouws, R.H. 1995. Woordeboeke met Afrikaans en Duits as taalpaar: 'n metaleksikografiese situering binne die Afrikaanse vertalende leksikografie. South African Joumal of Linguistics, Supplement 25: 1-87.

Gouws, R.H. and F.A. Ponelis. 1992. The Development of Afrikaans and the Lexicographical Tradition. Zgusta, L. (Ed.). 1992. History, Languages and Lexicographers: 77-104. Tübingen: Max Niemeyer.

Gouws, R., I. Feinauer and F. Ponelis. 1994. Basiswoordeboek van Afrikaans. Pretoria: J.L. van Schaik.

Grobbelaar, P. et al. (Eds.). 1987. Reader's Digest Afrikaans-Engelse Woordeboek / English-Afrikaans Dictionary. Cape Town: The Reader's Digest Association, South Africa (Pty) Ltd. 
Hansen, G.B. 1990. Artikelstruktur im zweisprachigen Wörterbuch. Tübingen: Max Niemeyer.

Hartmann, R.R.K. 1989. Sociology of the Dictionary User: Hypotheses and Empirical Studies. Hausmann, F.J. et al. (Eds.). 1989-1991: 102-111.

Hartmann, R.R.K. 1989a. The Dictionary as an Aid to Foreign-Language Teaching. Hausmann, F.J. et al. (Eds.). 1989-1991: 181-189.

Hausmann, F.J. and H.E. Wiegand. 1989. Component Parts and Structures of Monolingual Dictionaries. Hausmann, F.J. et al. (Eds.). 1989-1991: 328-360.

Hausmann, F.J. and R.O. Werner. 1991. Spezifische Bauteile und Strukturen zweisprachiger Wörterbücher: eine Übersicht. Hausmann, F.J. et al. (Eds.). 1989-1991: 2729-2769.

Hausmann, F.J. et al. (Eds.). 1989-1991. Wörterbücher. Dictionaries. Dictionnaires. An International Encyclopedia of Lexicography. Berlin: Walter de Gruyter.

Kotze, E. and P. Wela. 1991. Afrikaans / Zoeloe-woordeboek. Cape Town: Tafelberg Publishers.

Kromann, H.P. et al. 1991. Principles of Bilingual Lexicography. Hausmann, F.J. et al. (Eds.). 19891991: 2711-2728.

Kühn, P. 1989. Typologie der Wörterbücher nach Benutzungsmöglichkeiten. Hausmann, F.J. et al. (Eds.). 1989-1991: 111-127.

Lehrer, A. 1974. Semantic Fields and Lexical Structures. Amsterdam: North-Holland.

Louw, J.P. (Ed.). 1985. Lexicography and Translation. Cape Town: Bible Society of South Africa.

Lyons, J. 1977. Semantics. Cambridge: Cambridge University Press.

Odendal, F.F. 19943. Verklarende Handwoordeboek van die Afrikaanse Taal. Midrand: Perskor.

Takebayashi, S. and Y. Kojima (Eds.). 1990. Kenkyusha's Lighthouse English-Japanese Dictionary. Tokyo: Kenkyusha.

Wiegand, H.E. 1995. Lexikographische Texte in einsprachigen Lernerwörterbüchern. Kritische Überlegungen anläßlich des Erscheinens von Langenscheidts Großwörterbuch Deutsch als Fremdsprache. Popp, H. (Ed.). 1995. Deutsch als Fremdsprache. An den Quellen eines Faches: 463-499. München: Iudicisum.

Zöfgen, E. 1991. Bilingual Learner's Dictionaries. Hausmann, F.J. et al. (Eds.). 1989-1991: 28882903.

Zöfgen, E. 1994. Lernerwörterbücher in Theorie und Praxis. Tübingen: Max Niemeyer. 